\title{
Bacteriological evaluation of some sachet water on sales in Owerri metropolis, Imo State, Nigeria
}

\author{
Chinelo Mgbakor ${ }^{1 \star}$, G. C. Ojiegbe ${ }^{2}$, Iheanyi Omezuruike Okonko ${ }^{3 \star}$, Ngozi Nma Odu ${ }^{3}$, John Adeolu Alli ${ }^{1}$, Jonathan \\ Chukwudidi Nwanze ${ }^{4}$ and Charles Chukwuemeka Onoh ${ }^{4}$ \\ ${ }^{1}$ Department of Medical Microbiology and Parasitology, University College Hospital, Ibadan, Oyo State, Nigeria. \\ ${ }^{2}$ Department of Medical Laboratory Science, Imo State University, Owerri, Imo State, Nigeria. \\ ${ }^{3}$ Department of Microbiology, University of Port Harcourt, Choba, P.M.B 5323 Port Harcourt, River State, Nigeria. \\ ${ }^{4}$ Department of Pharmacology and Therapeutics, Igbinedion University, Okada, Edo State, Nigeria. \\ E-mail: jmgbakor@yahoo.com
}

Received 12 May 2011; received in revised form 25 August 2011; accepted 18 September 2011

\begin{abstract}
Aims: Continuous increase in the sale and indiscriminate consumption of packaged drinking waters in Nigeria is of public health significance. In order to safe guard public health, it is essential that the available packaged water is of the highest quality. This study was carried out to evaluate the bacteriological quality of packaged water on sale in Owerri metropolis, Imo State of Nigeria.

Methodology and Results: From 30 registered sachet water factories, 8 samples each was purchased randomly fifteen of the brands of sachet water all over Owerri metropolis in Imo State, Southeastern Nigeria. These were analyzed for presence of bacterial indicators of water quality. Four weeks later, a second batch of the samples was collected from other brands. A mean plate counts was taken and the organisms from each water sample identified using standard procedures. The results showed that $11(73.3 \%)$ sachet water brands had growths of pathogenic organisms in the first batch while $10(66.6 \%)$ had growth in the second batch. The isolates were identified to be Klebsilla spp., Serratia spp., Proteus spp., Pseudomonas aeruginosa and Chromobacterium spp. The study showed that Klebsiella pneumoniae $[7(29.2 \%)]$ was the most predominant. This was closely followed by Serratia spp. [6(25.0\%)] and Proteus mirabilis [6(25.0\%)]. Pseudomonas aeruginosa [3(12.5\%)] and Chromobacterium spp. [2(8.3\%)] was least predominant. Mean total heterotrophic bacteria plate counts (HPC) per millilitre ranged from 0.0 to $6.0 \times 10^{2} \mathrm{CFU} / \mathrm{mL}$ at $22{ }^{\circ} \mathrm{C}$ and 0.0 to 7.0 $\times 10^{2} \mathrm{CFU} / \mathrm{mL}$ at $37{ }^{\circ} \mathrm{C}$ (first batch) and 0.0 to $5.0 \times 10^{2} \mathrm{CFU} / \mathrm{mL}$ at $22{ }^{\circ} \mathrm{C}$ and 0.0 to $10.0 \times 10^{2} \mathrm{CFU} / \mathrm{mL}$ at $37^{\circ} \mathrm{C}$ for the second batch. Thus they fell below the United States Environmental Protection Agency (USEPA) and World Health Organization (WHO) drinking water standard of 100 HPC per millilitre of water. Bacteriological examination of different brands of sachet water samples collected from different locations showed that only Vince water and Akudo table water was found to be safe for drinking while the other brands of sachet water from mobile vendors in Owerri metropolis was not potable.

Conclusion, Significance and Impact of study: Hence, the bacteriological quality of some of the brands of sachet water on sale in Owerri was of poor quality index. The study suggests that sachet water could be a route of transmission of enteric pathogens among the populace. In order to safe guard public health, highest quality brands of sachet water is therefore advocated.
\end{abstract}

Keywords: Bacteriological quality, drinking water, evaluation, sachet water, Owerri metropolis, Southeastern Nigeria

\section{INTRODUCTION}

In recent years, sale of packaged water has been on the increase in most urban cities in Nigeria. In order to safe guard public health, it is essential that the available packaged water is of the highest quality (Anunobi et al. 2006). The continuous increase in the sale and indiscriminate consumption of packaged drinking waters in Nigeria is of public health significance. The sale and consumption of packaged water continues to grow rapidly in most countries of the world. In Nigeria particularly, there is an astronomical increase in the consumption of packaged waters especially bottled and sachet drinking water (Oyedeji et al., 2010).

The increased demand for these drinking water products is attributed largely to factors such as inadequate or non availability of reliable, safe municipal water in urban areas; impression that high quality natural spring water and drinking water offer a healthy, refreshing and great tasting alternative to high calorie soft drinks and ordinary tap water; and convenience which has made the products meet the requirements of any lifestyle when needed (Oyedeji et al., 2010).

The recent introduction of sachet water to consumers was to provide safe, hygienic and affordable instant 
drinking water to the public and to curb the magnitude of water borne infections in the communities. Although this is a laudable idea, current trends seem to suggest that sachet drinking water could be a route of transmission of enteric pathogens. The overall treatment of source water is dependent in the quality of source water, type of sache water being manufactured and location (Wartburton et al., 1998; Khaniki et al., 2010). Earlier investigation conducted on the safety of drinking water has show that water on the market is of good microbiological quality while the quality of some factory bagged sachet and hand-filled polythene bagged drinking water was noted to be doubtful (Oladipo et al., 2009; Oyedeji et al., 2010). This observation was based on studies carried out on water sample to ascertain the presence of heterotrophic bacteria, indicators of fecal contamination (total coliform, fecal coliforms and Enterococci) and for lead, manganese and iron (Oladipo et al., 2009).

Coliform bacteria describe a group of enteric bacteria that includes E. coli, Klebsiella species and Enterobacter species. They are Gram negative, facultatively anaerobic, non sporing rods that may be motile or not. They are able to ferment lactose to produce acid and gas within $48 \mathrm{~h}$ at $35{ }^{\circ} \mathrm{C}$ (Oyedeji et al., 2010). Although they are generally not harmful themselves, they indicate the possible presence of pathogenic bacteria, viruses and protozoans (Oyedeji et al., 2010). Members of the faecal coliform group especially $E$. coli are used as indicators of possible recent sewage / faecal contamination because they are commonly found in human and animal faeces. Other microbial indicators of possible faecal contamination are faecal enterococci especially $E$. faecalis and Clostridium perfringens spores.

Studies carried out in different areas of world indicate that most of the sources of domestic water have an alarming level of microbiological pollution (Mpakam, 2009; Oladipo et al., 2009; Prasanna and Reddy, 2009; Kuitcha et al., 2010; Khaniki et al., 2010; Oyedeji et al., 2010). Microbial contamination by human or animal excreta is the most common reason for water to be considered unsafe for drinking because of the high probability of presence of pathogenic organisms (Oyedeji et al., 2010).

Lack of information on pathogenic organisms in sachet water on our market creates some uncertainties in our understanding of the overall quality of drinking water on our markets (Oladipo et al., 2009). Therefore, this study was carried out to evaluate the bacteriological quality of packaged water on sale in Owerri metropolis, Imo State, Southeastern Nigeria. This will give an understanding of the extent to which the products meet the standards and recommendations of the World Health Organization (WHO).

\section{MATERIALS AND METHODS}

\section{Collection of samples}

From our investigation, there were 30 registered sachet water factories in Owerri metropolis, $50.0 \%$ of this population was evaluated. Hence, 15 brands of sachet water factories were evaluated. One hundred and twenty (120) samples of $500 \mathrm{~mL}$ vended sachet water were randomly purchase from market places, schools and campuses, motor parks etc. in Owerri Southeastern Nigeria. After four (4) weeks, another batch of the 120 samples was collected. Table 1 show the summary of 15 brands of sachet water on sales in Owerri Southeastern Nigeria. It showed the number of samples collected.

Table 1: Summary of vended sachet water from different locations in Southeastern Nigeria.

\begin{tabular}{llll}
\hline \multirow{2}{*}{ Code } & Brand Name & \multicolumn{2}{c}{ No. Tested } \\
\cline { 3 - 4 } & $\begin{array}{l}\text { First } \\
\text { batch }\end{array}$ & $\begin{array}{l}\text { Second } \\
\text { batch }\end{array}$ \\
\hline S01 & Chipa table water & 08 & 08 \\
S02 & Hanek table water & 08 & 08 \\
S03 & Jesus loves you table & 08 & 08 \\
& water & & \\
S04 & Malyn table water & 08 & 08 \\
S05 & Agad table water & 08 & 08 \\
S06 & Davimor table water & 08 & 08 \\
S07 & Mr Ben table water & 08 & 08 \\
S08 & Enodoz table water & 08 & 08 \\
S09 & Vince water & 08 & 08 \\
S10 & Mevok table water & 08 & 08 \\
S11 & Maco water & 08 & 08 \\
S12 & T and C water & 08 & 08 \\
S13 & Damino table water & 08 & 08 \\
S14 & Akudo table water & 08 & 08 \\
S15 & God is able table water & 08 & 08 \\
& Total & 120 & 120 \\
\hline
\end{tabular}

\section{Bacteriological analysis}

All the chemicals and reagents used were of analytical grade, obtained from Sigma chemical co. Ltd, England. The media used for the bacteriological analysis of sachet water include plate count agar (PCA) and Mac Conkey agar (MCA). All the media used were weighed out and prepared according to the manufacturer's specification, with respect to the given instructions and directions and sterilized at $121{ }^{\circ} \mathrm{C}$ for $15 \mathrm{~min}$. at $15 \mathrm{lb}$ pressure. A serial dilution method was used. The sterility of each batch of test medium was confirmed by incubating one or two uninoculated plates along with the inoculated plates. The uninoculated plates were always examined to show no evidence of bacterial growth. Any uninoculated plate that showed evidence of bacterial growth was discarded. All the samples and the test organisms were replicated on different media and the plates were then incubated at both $37^{\circ} \mathrm{C}$ and $22^{\circ} \mathrm{C}$ for $24-48 \mathrm{~h}$. Discrete colonies were subcultured into fresh agar plates aseptically to obtain pure cultures of the isolates. Colonies identifiable as discrete on the Mueller Hinton Agar were carefully examined macroscopically for cultural characteristics. All isolates were subjected to various morphological characterization and Gram stained to determine their gram reaction. Biochemical tests were carried out as described by Jolt et 
al. (1994) to determine the identity of the bacteria isolates with reference to Bergey's Manual of Determinative Bacteriology. The isolates were identified by comparing their characteristics with those of known taxa, as described by Jolt et al. (1994), Cheesbrough (2006) and Oyeleke and Manga (2008).

\section{Total heterotrophic bacteria plate counts (HPC)}

The total heterotrophic bacteria plate counts (HPC) in the water samples were obtained using the standard pour plate technique. Dilutions of water samples in buffered peptone water were inoculated in $1 \mathrm{~mL}$ aliquots into each of $10 \mathrm{~mL}$ molten standard plate count agar in Mac Cartney bottles. After thorough mixing, these were poured into sterile Petri dishes and incubated for $24-48 \mathrm{~h}$ at $22{ }^{\circ} \mathrm{C}$ and $37{ }^{\circ} \mathrm{C}$. Petri dishes from dilutions containing 50 discrete colonies were counted and the results expressed as the numbers of bacteria colonies per millilitre $(\mathrm{CFU} / \mathrm{mL})$. However, no total coliform count or faecal coliform count was carried out.

\section{Statistical analysis}

The HPC counts of duplicate batches of the various brands of sachet-packed drinking waters were evaluated with the statistical program for the social sciences (SPSS) version 17. The mean of total heterotrophic bacteria plate counts per $\mathrm{ml}$ was used to summarize the microbial quality of the packaged waters in this study.

\section{RESULTS}

One hundred and twenty (120) samples of sachet water in Owerri Southeastern Nigeria were evaluated. After four (4) weeks, another batch of the 120 samples was also evaluated. Table 2 shows the mean plate count of viable growth of microorganisms isolated from the first batch of sachet water on sales in Owerri metropolis, Imo State of Nigeria.

From the evaluation of the first batch of 15 brands of sachet water on sales in Owerri metropolis, Imo State of Nigeria, $11(73.3 \%)$ brands yielded specific growth of microorganisms after $24 \mathrm{~h}$ of incubation both at $37{ }^{\circ} \mathrm{C}$ and $22{ }^{\circ} \mathrm{C}$ while $4(22.7 \%)$ brands yielded no growth of microorganisms after $72 \mathrm{~h}$ of incubation (Table 2).

Also, from the evaluation of the second batch of 15 brands of sachet water on sales in Owerri metropolis, Imo State of Nigeria, $10(66.7 \%)$ brands yielded specific growth of microorganisms after $24 \mathrm{~h}$ of incubation both at $37^{\circ} \mathrm{C}$ and $22^{\circ} \mathrm{C}$ while 5 (33.3\%) brands yielded no growth of microorganisms after $72 \mathrm{~h}$ of incubation (Table 2). However, $70.0 \%$ of all brands of packaged water that was registered by NAFDAC had a higher microbial growth indicating low bacteriological quality.

Table 3 shows distribution and frequency of occurrence of microorganisms isolated from the second batch of sachet water on sales in Owerri metropolis, Imo State of Nigeria. It showed that Klebsiella pneumoniae $[7(29.2 \%)]$ was the most predominant organisms recovered from different brands of sachet water evaluated. This was closely followed by Serratia spp. [6(25.0\%)] and Proteus mirabilis [6(25.0\%)]. Pseudomonas aeruginosa [3(12.5\%)] and Chromobacterium spp. [2(8.3\%)] was least predominant (Table 3).

Table 2: Distribution of microbial growth pattern of sachet water on sales in Owerri metropolis, Imo State of Nigeria.

\begin{tabular}{llll}
\hline Batches & $\begin{array}{l}\text { Brands } \\
\text { tested (\%) }\end{array}$ & $\begin{array}{l}\text { No. with } \\
\text { growth } \\
(\%)\end{array}$ & $\begin{array}{l}\text { No. } \\
\text { without } \\
\text { growth } \\
(\%)\end{array}$ \\
\hline First batch & $15(50.0)$ & $11(73.3)$ & $04(26.7)$ \\
Second Batch & $15(50.0)$ & $10(66.7)$ & $05(33.3)$ \\
$\begin{array}{l}\text { Total of } \\
\text { registered }\end{array}$ & $30(100.0)$ & $21(70.0)$ & $09(30.0)$ \\
brands in Owerri & & & \\
\hline
\end{tabular}

Table 3: Distribution and frequency of occurrence of microorganisms isolated from the second batch of sachet water on sales in Owerri metropolis, Imo State of Nigeria.

\begin{tabular}{|c|c|c|c|}
\hline Isolates & No. (\%) & $\begin{array}{l}\text { First } \\
\text { batch (\%) }\end{array}$ & $\begin{array}{l}\text { Second } \\
\text { batch } \\
(\%)\end{array}$ \\
\hline Serratia spp. & $6(25.0)$ & $3(50.0)$ & $3(50.0)$ \\
\hline $\begin{array}{l}\text { Klebsiella } \\
\text { pneumoniae }\end{array}$ & $7(29.2)$ & $4(57.1)$ & $3(42.9)$ \\
\hline Proteus mirabilis & $6(25.0)$ & $1(16.7)$ & $5(83.3)$ \\
\hline $\begin{array}{l}\text { Chromobacterium } \\
\text { spp. }\end{array}$ & $2(08.3)$ & $1(50.0)$ & $1(50.0)$ \\
\hline $\begin{array}{l}\text { Pseudomonas } \\
\text { aeruginosa }\end{array}$ & $3(12.5)$ & $1(33.3)$ & $2(66.7)$ \\
\hline Total & $24(100.0)$ & $10(41.7)$ & $14(58.3)$ \\
\hline
\end{tabular}

Table 4 shows the total heterotrophic bacteria plate counts (HPC) and microorganisms isolated from the first batch of sachet water on sales in Owerri metropolis, Imo State of Nigeria. It showed that of 15 brands evaluated in the first batch, 11 (73.3\%) had microbial growth and 4 (22.7) had no growth. It also showed that the mean total heterotrophic bacteria plate counts (HPC) per millilitre of sachet water on sale in Owerri, Imo State ranges from 0.0 to $6.0 \times 10^{2} \mathrm{CFU} / \mathrm{mL}$ at $22^{\circ} \mathrm{C}$ and 0.0 to $7.0 \times 10^{2} \mathrm{CFU} / \mathrm{mL}$ at $37^{\circ} \mathrm{C}$.

The evaluation of the first batch of sachet water on sales in Owerri, Imo State, showed that no microbial load was found in four brands, Imo State and this include Davimor table water, Vince table water, Maco water and Akudo table water (Table 4). Also, among 15 brands evaluated in the first batch, Chipa table water and Agad table water had the highest mean HPC of $7.0 \times 10^{2}$ $\mathrm{CFU} / \mathrm{mL}$ at $37{ }^{\circ} \mathrm{C}$. This was followed by Jesus loves you table water and Domino table water of mean HPC $6.0 \mathrm{x}$ $10^{2} \mathrm{CFU} / \mathrm{mL}$ at $37^{\circ} \mathrm{C}$, Malyn table water, Mr Ben table water, Enodoz table water and $\mathrm{T}$ and $\mathrm{C}$ water of mean 
HPC $5.0 \times 10^{2} \mathrm{CFU} / \mathrm{mL}$ at $37^{\circ} \mathrm{C}$. However, mean total heterotrophic bacteria plate counts (HPC) per millilitre ranged from 0.0 to $6.0 \times 10^{2} \mathrm{CFU} / \mathrm{mL}$ at $22{ }^{\circ} \mathrm{C}$ and 0.0 to $7.0 \times 10^{2} \mathrm{CFU} / \mathrm{mL}$ at $37^{\circ} \mathrm{C}$ (first batch) and thus fell below the United States Environmental Protection Agency (USEPA) and World Health Organization (WHO) drinking water standard of $100 \mathrm{HPC}$ per millilitre water.

Table 5 shows the mean total heterotrophic bacteria plate counts (HPC) and microorganisms isolated from the second batch of sachet water on sales in Owerri metropolis, Imo State of Nigeria. It showed that of the second batch of 15 brands of sachet water evaluated, 10 $(66.7 \%)$ brands had microbial growth after $24 \mathrm{~h}$ of incubation both at $37{ }^{\circ} \mathrm{C}$ and $22{ }^{\circ} \mathrm{C}$ while 5 (33.3\%) brands had no growth after $72 \mathrm{~h}$ of incubation (Table 5). It also showed that no microbial load was found in five brands, Imo State and this include T \& C water, Agad, Mr Ben, Vince and Akudo table water (Table 5).

Table 4: Mean total heterotrophic bacteria plate counts (HPC) and microorganisms isolated from the first batch of sachet water on sales in Owerri metropolis, Imo State of Nigeria.

\begin{tabular}{|c|c|c|c|c|c|c|c|}
\hline \multirow[t]{2}{*}{ Code } & \multirow[t]{2}{*}{ Brand Name } & \multirow{2}{*}{$\begin{array}{l}\text { No. } \\
\text { Tested }\end{array}$} & \multicolumn{2}{|c|}{$\begin{array}{l}\text { No. with growth } \\
\text { at temperature }\end{array}$} & \multicolumn{2}{|c|}{$\begin{array}{l}\text { Mean total HPC } \\
\left(\times 10^{2} \mathrm{CFU} / \mathrm{mL}\right)\end{array}$} & \multirow[t]{2}{*}{ Organisms isolated } \\
\hline & & & $37^{\circ} \mathrm{C}$ & $22^{\circ} \mathrm{C}$ & $37^{\circ} \mathrm{C}$ & $22^{\circ} \mathrm{C}$ & \\
\hline S01 & Chipa table water & 08 & 05 & 04 & 07 & 06 & Serratia spp. \\
\hline S02 & Hanek table water & 08 & 06 & 06 & 03 & 04 & Klebsiella pneumoniae \\
\hline S03 & $\begin{array}{l}\text { Jesus loves you table } \\
\text { water }\end{array}$ & 08 & 08 & 07 & 06 & 03 & Klebsiella pneumoniae \\
\hline S04 & Malyn table water & 08 & 08 & 05 & 05 & 10 & Serratia spp. \\
\hline S05 & Agad table water & 08 & 03 & 02 & 07 & 05 & Pseudomonas aeruginosa \\
\hline S06 & Davimor table water & 08 & 00 & 00 & 00 & 00 & No growth \\
\hline S07 & Mr Ben table water & 08 & 05 & 03 & 05 & 04 & Klebsiella pneumoniae \\
\hline S08 & Enodoz table water & 08 & 04 & 03 & 05 & 02 & Pseudomonas aeruginosa \\
\hline S09 & Vince water & 08 & 00 & 00 & 00 & 00 & No growth \\
\hline S10 & Mevok table water & 08 & 02 & 02 & 02 & 01 & Klebsiella pneumoniae \\
\hline S11 & Maco water & 08 & 00 & 00 & 00 & 00 & No growth \\
\hline S12 & $\mathrm{T}$ and $\mathrm{C}$ water & 08 & 06 & 03 & 05 & 02 & Proteus mirabilis \\
\hline S13 & Domino table water & 08 & 04 & 04 & 06 & 03 & Serratia spp. \\
\hline S14 & Akudo table water & 08 & 00 & 00 & 00 & 00 & No growth \\
\hline S15 & God is able table water & 08 & 02 & 02 & 04 & 06 & Chromobacterium spp. \\
\hline
\end{tabular}

Table 5: Mean total heterotrophic bacteria plate counts (HPC) and microorganisms isolated from the second batch of sachet water on sales in Owerri metropolis, Imo State of Nigeria.

\begin{tabular}{|c|c|c|c|c|c|c|c|}
\hline \multirow[t]{2}{*}{ Code } & \multirow[t]{2}{*}{ Brand Name } & \multirow{2}{*}{$\begin{array}{l}\text { No. } \\
\text { Tested }\end{array}$} & \multicolumn{2}{|c|}{$\begin{array}{l}\text { No. with growth } \\
\text { at temperature }\end{array}$} & \multicolumn{2}{|c|}{$\begin{array}{l}\text { Mean total HPC } \\
\left(\times 10^{2} \mathrm{CFU} / \mathrm{mL}\right)\end{array}$} & \multirow[t]{2}{*}{ Organisms isolated } \\
\hline & & & $37^{\circ} \mathrm{C}$ & $22{ }^{\circ} \mathrm{C}$ & $37^{\circ} \mathrm{C}$ & $22^{\circ} \mathrm{C}$ & \\
\hline S01 & Chipa table water & 08 & 05 & 06 & $04 / 03$ & $05 / 03$ & $\begin{array}{l}\text { Serratia spp., Proteus } \\
\text { mirabilis }\end{array}$ \\
\hline S02 & Hanek table water & 08 & 08 & 06 & 05 & 04 & Klebsiella pneumoniae \\
\hline S03 & $\begin{array}{l}\text { Jesus loves you table } \\
\text { water }\end{array}$ & 08 & 06 & 04 & 06 & 03 & Proteus mirabilis \\
\hline S04 & Malyn table water & 08 & 08 & 08 & 10 & 06 & Klebsiella pneumoniae \\
\hline S05 & Agad table water & 08 & 00 & 00 & 00 & 00 & No growth \\
\hline S06 & Davimor table water & 08 & 06 & 02 & 03 & 01 & Chromobacterium spp. \\
\hline S07 & Mr Ben table water & 08 & 00 & 00 & 00 & 00 & No growth \\
\hline S08 & Enodoz table water & 08 & 08 & 08 & 07 & 05 & Serratia spp. \\
\hline S09 & Vince water & 08 & 00 & 00 & 00 & 00 & No growth \\
\hline S10 & Mevok table water & 08 & 05 & 04 & 03 & 02 & Proteus mirabilis \\
\hline S11 & Maco water & 08 & 06 & 05 & $06 / 04$ & $05 / 03$ & $\begin{array}{l}\text { Serratia spp., Proteus } \\
\text { mirabilis }\end{array}$ \\
\hline S12 & $\mathrm{T}$ and $\mathrm{C}$ water & 08 & 00 & 00 & 00 & 00 & No growth \\
\hline S13 & Domino table water & 08 & 06 & 06 & 06/03 & 05/02 & $\begin{array}{l}\text { Klebsiella pneumoniae, } \\
\text { Pseudomonas aeruginosa }\end{array}$ \\
\hline S14 & Akudo table water & 08 & 00 & 00 & 00 & 00 & No growth \\
\hline S15 & God is able table water & 08 & 04 & 04 & 06 & 03 & Proteus mirabilis \\
\hline
\end{tabular}


The mean total heterotrophic bacteria plate counts (HPC) of the second batch of sachet water sold in Owerri, Imo State ranges from 0.0 to $5.0 \times 10^{2} \mathrm{CFU} / \mathrm{mL}$ at $22{ }^{\circ} \mathrm{C}$ and 0.0 to $10.0 \times 10^{2} \mathrm{CFU} / \mathrm{mL}$ at $37^{\circ} \mathrm{C}$. Also, among 15 brands evaluated in the second batch, Malyn table water had the highest mean HPC of $10.0 \times 10^{2} \mathrm{CFU} / \mathrm{mL}$ at $37^{\circ} \mathrm{C}$ This was followed by Enodoz table water with mean HPC of $7.0 \times 10^{2} \mathrm{CFU} / \mathrm{mL}$ at $37^{\circ} \mathrm{C}$, Jesus loves you table water, Maco water, Domino table water, and God is able table water with mean HPC of $6.0 \times 10^{2} \mathrm{CFU} / \mathrm{mL}$ at $37^{\circ} \mathrm{C}$, Chipa table water and Hanek table water with mean HPC of $5.0 \times 10^{2} \mathrm{CFU} / \mathrm{mL}$ at $37^{\circ} \mathrm{C}$ while Davimor table water and Mevok table water had a lower mean HPC of $3.0 \mathrm{x}$ $10^{2} \mathrm{CFU} / \mathrm{mL}$ at $37{ }^{\circ} \mathrm{C}$. However, the mean total heterotrophic bacteria plate counts (HPC) per millilitre ranged from 0.0 to $5.0 \times 10^{2} \mathrm{CFU} / \mathrm{mL}$ at $22{ }^{\circ} \mathrm{C}$ and 0.0 to $10.0 \times 10^{2} \mathrm{CFU} / \mathrm{mL}$ at $37^{\circ} \mathrm{C}$ and thus fell below the United States Environmental Protection Agency (USEPA) and World Health Organization (WHO) drinking water standard of $100 \mathrm{HPC}$ per millilitre of water.

\section{DISCUSSION}

Access to safe drinking water is a vital agent for living of human (Khaniki et al., 2010). Hence, this study was carried out to evaluate the bacteriological quality of some sachet water on sales in Owerri metropolis, Imo State of Nigeria. Owerri metropolis are highly urbanized areas in Southeastern Nigeria where several brands of bottled and sachet water are vended to the public. The choice of Owerri in Imo State is based on the fact that it is the major area where sachet water consumption is high. The continuous proliferation of these packaged water products and their indiscriminate consumption are of public health significance. An understanding of their microbiological quality and safety are therefore imperative (DWRF, 2004).

In this study, it was found that as temperature of incubation increased from $22{ }^{\circ} \mathrm{C}$ to $37^{\circ} \mathrm{C}$, the rate of growth of all the isolates increased. It is interesting to note that the organisms isolated in this study were capable of growth at both $22{ }^{\circ} \mathrm{C}$ and $37{ }^{\circ} \mathrm{C}$ temperatures (Table 4 and 5). This is a deviation from what was reported by Oladipo et al. (2009) who reported a decrease in growth of isolates as temperature of incubation increased from 50 to $80^{\circ} \mathrm{C}$.

In this study, $70.0 \%$ of all brands of sachet water that was registered by NAFDAC had a higher microbial growth indicating low bacteriological quality. This is a deviation from the findings of Anunobi et al. (2006) who reported that packaged water that was registered by NAFDAC had a higher bacteriological quality compared to unregistered ones in their study on packaged water in Onitsha metropolis, Southeastern Nigeria.

In this study, mean total heterotrophic bacteria plate counts (HPC) per millilitre ranged from 0.0 to $6.0 \times 10^{2}$ $\mathrm{CFU} / \mathrm{mL}$ at $22{ }^{\circ} \mathrm{C}$ and 0.0 to $7.0 \times 10^{2} \mathrm{CFU} / \mathrm{mL}$ at $37^{\circ} \mathrm{C}$ (first batch) and 0.0 to $5.0 \times 10^{2} \mathrm{CFU} / \mathrm{mL}$ at $22^{\circ} \mathrm{C}$ and 0.0 to $10.0 \times 10^{2} \mathrm{CFU} / \mathrm{mL}$ at $37^{\circ} \mathrm{C}$ for the second batch. Thus, they fell below the United States Environmental
Protection Agency (USEPA) and World Health Organization (WHO) drinking water standard of $100 \mathrm{HPC}$ per millilitre of water. This is similar to what has been previously reported by other researchers. Khaniki et al. (2010) reported HPCs values ranging from $2.4 \times 10^{1}$ to $9.50 \times 10^{2} \mathrm{CFU} / \mathrm{mL}$

According to World Health Organization report (WHO, 2002), a high HPC concentration does not itself present a risk to human health. Nevertheless, HPCs are used as good indicators of the overall quality of production (Oyedeji et al., 2010). These may therefore, be used in assessing the cleanliness of the different brands of bottle and sachet drinking waters sold in the selected areas of study (Taulo et al., 2008; Oyedeji et al., 2010). However, based on the recommended standard limits of 100 HPC per millilitre of drinking water by USEPA and WHO, 70.0 $\%$ of sachet water from domestic commercial brands on sales in Owerri metropolis could be considered unsuitable for human consumption. In line with the assertions of Khaniki et al. (2010), implementation of hazard analysis critical control points (HACCP) for the microbial quality of packaged water in all processing from raw water to final production, to control contamination during packaging and prohibit microbial growth during storage and distribution can be terminated to receive safe water.

According to this study, HPCs were also zero among the brands of sachet water (Maco water, Davimor table water, Vince water, and Akudo table water) in the first batch (Table 4) and Agad, Mr Ben, T \& C, Vince, and Akudo table water in the second batch examined (Table $5)$. It was more than zero in the other brands of sachet water (Table 4 and 5). According to Khaniki et al. (2010), it showed that the quality of these waters is somewhat unhealthy for public consumption. Although in none of the brands were isolates of $E$. coli and $E$. faecalis but it may exist in other brands that have not been examined, because $E$. coli has the potential to multiply and then survive for over 40 days in artificially inoculated bottled water (Wartburton et al., 1998; WHO, 2006; Kokkinakis et al., 2008; Khaniki et al., 2010). The presence of E. coli in water is nearly always associated with recent faecal pollution and it is the preferred indicator organism for this purpose (Khaniki et al., 2010).

In our study, neither E. coli nor Enterococcus faecalis was found in any of the examined sachet water samples. Though, no total coliform count or faecal coliform count was carried out in our study, K. pneumonae (also a faecal coliform) was reported in $40.0 \%$ of the sachet water. This suggests the presence of faecal contamination at these samples, thereby giving an indication concerns over the bacteriological quality of sachet water on sales in Owerri, Imo State, Nigeria. This deviate from what was somewhat reported elsewhere in and outside Nigeria by some authors (Ehlers et al., 2004; Anunobi et al., 2006; Abayasekara et al., 2007; Prasanna and Reddy, 2009; Kuitcha et al., 2010; Khaniki et al., 2010). It is important to identify if sachet water is contaminated and to prevent the consumption of these samples (Khaniki et al., 2010). 
HPC can be one of the microbiological parameters to be determined in order to control the quality of water for human consumption (Khaniki et al., 2010). In this study, brands of Vince water and Akudo table water had HPC lower than standard level during evaluation periods. There are many reports that viable counts can increase to $10^{4}$. $10^{5} \mathrm{CFU} / \mathrm{mL}$ after 1 - 2 weeks of storage (Khaniki et al., 2010). Earlier investigation conducted on the safety of drinking water in some other parts of Nigeria has show that water on the market is of good microbiological quality while the quality of some factory bagged sachet and handfilled polythene bagged drinking water was noted to be doubtful (Oladipo et al., 2009; Oyedeji et al., 2010). Lack of information on pathogenic bacteria in sachet water on our market creates some uncertainties in our understanding of the overall quality of drinking water on our markets. Ajayi et al. (2008) had reported an earlier study of packaged drinking waters in Ibadan, Nigeria in which larger proportions of sachet water were found to show positive coliform counts compared to bottled waters.

The prevalence of the organisms is shown in Table 3. Bacteria were recovered in 11 of 15 brands of sachet water in first batch and in 10 of 15 brands of sachet water examined in second batch of the study. All the organisms recovered in this study were members of the family Enterobacteriaceae. From both batches of 15 brands of sachet water, the isolates recovered include $K$ pneumoniae, (29.2 \%) which was most predominant organisms. This was closely followed by Serratia spp. and P. mirabilis (25.0 \%). P. aeruginosa (12.5\%) and Chromobacterium spp. (8.3\%) was found to be least predominant (Table 3, 4 and 5). However, K. pneumoniae predominated in the first batch of sachet water (Table 3 and 4) while $P$. mirabilis predominated in the second batch of sachet water evaluated (Table 3 and 5). These bacteria have been implicated in water related diseases (Oladipo et al., 2009).

None of the samples were positive for $E$. coli or $E$. faecalis except for $K$. pneumoniae. The presence of $K$. pneumoniae in sachet water suggests the potential presence of pathogenic enteric microorganisms and it requires an improved surveillance system for the sachet packaged water industry. In drinking water from sachet, the coliform test can be used as quality index, an indicator of treatment efficiency and the integrity of the production system (Khaniki et al., 2010). This is in line with the findings of some other authors in Nigeria and outside (Addo et al., 2009). However, the occurrence of these isolates in sachet water used in this study is in contrast with the findings of some other studies in Nigeria which found no enteric pathogens (Egwari et al., 2005; Ekwunife et al., 2010). Our findings also differ from other study in that no $E$. coli and $E$. faecalis were recovered as was reported in a study by Oyedeji et al. (2010).

In this study, the bacteriological quality of some of the sachet water sold in Owerri metropolis, Imo State, was found to be of very poor quality index because it contains certain pathogenic organisms. Of the 15 brands examined, only 4 (from the first batch) and 5 (from the second batch) had no microbial growth. Several studies
(Wartburton et al., 1998; Kwakye-Nuako et al., 2007; Onifade et al., 2008; Dada, 2009; Oyedeji et al., 2010) on the microbial quality of bottled and sachet water have reported violations of international quality standards. In a study carried out in Canadian, screening of bottled water for indicator bacteria revealed that $3.7 \%$ of the samples had total coliforms and $23.3 \%$ had more than 100 colonies of heterotrophic bacteria per $\mathrm{mL}$ of sample (Warburton et al., 1998). A similar study of brands of bottled water in Trinidad revealed the presence of total coliforms, $E$. coli and colonies of $E$. faecalis in the samples (Oyedeji et al., 2010). The quality monitoring of sachet water in Nigeria have been documented (Onifade et al., 2008; Dada, 2009; Oyedeji et al., 2010). However, there is little information in scientific literatures on the quality of the many brands of bottled water produced and marketed by local and multinational companies.

The organisms recovered in this study have been previously reported by some other researchers. The organisms isolated in this study were similar to those commonly encountered in water and aquatic environments. Similar organisms have been reported in previous studies on water in Nigeria and outside Nigeria (Okonko et al., 2008; Prasanna and Reddy, 2009; Oyedeji et al., 2010). In a study, Prasanna and Reddy (2009) reported the presence of $P$. aeruginosa in the water of mobile vendors and ground water of Jeedimetla area, Hyderabad, India. In Cameroun, Kuitcha et al. (2010) reported similar organisms (Klebsiella pneumonia, Proteus vulgaris and Pseudomonas sp.) in their study.

The presence of these bacteria in some brands of sachet water examined in this study was really baffling. These bacteria might have contaminated the water from source (Okonko et al., 2008; Taulo et al., 2008). The presence of these bacteria isolated in the presumed treated sachet water used in this study may be as a result of improper handling, processing and purification procedures, unhygienic handling after production. It may also be attributed to many or more of the following; contamination of treated water by organism's harboured in connecting tubes to the packaging machines; lack of or poor quality control system, otherwise the level of treatment of the source water would have been identified before packaging; poor treatment mechanism, it is possible that the equipment or machines used in the purification were not functioning effectively. Also, the microbial contaminations of packaged drinking water could be influenced by factors such as their raw water source, treatment process employed and hygienic practices observed in production (Oyedeji et al., 2010).

In this study, $K$. pneumoniae was reported as the most predominant organism. Bacteria from genus Klebsiella causes numerous infections in human. A variety of nosocomial and community acquired (food borne) infections are caused by K. pneumoniae, one of the most deadly pathogens of Enterobactericeae. Also the presence of $P$. aeruginosa, in this study, a pathogenic organism renowned for its high resistance to antibiotics, is a cause for concern (Oladipo et al., 2009). Abed and Alwakeel (2007) reported that there is contamination with 
Pseudomonas sp. in $6.7 \%$ of the water sampled. Presence of $P$. aeruginosa and $P$. mirabilis in some vended sachet water was also reported by Oladipo et al (2009) in Ogbomoso, Nigeria. The P. aeruginosa isolated from the sachet water could probably have come from the raw food materials, apron, dust and palms of the handlers. $P$. aeruginosa isolated from these samples could be an evidence of cross contamination. $P$. mirabilis has also been reported by Oladipo et al. (2009) in a study on the bacteriological quality and safety of sachet water, and attributed to burst pipes along distribution lines of drinking water or unhygienic handling of water right from treatment plant used in the production of such water (Okonko et al., 2008; Oladipo et al., 2009).

Presence of these bacteria in water may be unnoticed even in transparent packaged water and the presence of these microorganisms may pose a potential risk to consumers. Even the consumption of such contaminated water may facilitate the widespread of infections and can ultimately lead to outbreak of epidemic (Oladipo et al., 2009). The possible health hazard of drinking contaminated or poorly treated water is tremendous, as water related diseases continue to be one of the major health problems globally (Oladipo et al., 2009). However, transmission of water borne disease is still a major public health concern despites considerable efforts and modern technology being utilized for the production of safe drinking water (Zamberlan et al., 2008) and it is important to know microbial quality of sachet water (Khaniki et al., 2010).

The overall treatment of source water is dependent in the quality of source water, type of sachet water being manufactured and location (Wartburton et al., 1998; Khaniki et al., 2010). The bacteriological quality of sachet water is of paramount importance and monitoring must be given highest priority, this is so because studies have attributed several disease outbreaks to untreated or poorly treated water containing bacteria pathogen that have been isolated from some of this sachet water used in this study. Therefore, maintaining a safe drinking water remains essential to human health as transient bacteria contamination may have implication well beyond a period of acute-self-limited illness. However, to ensure that the bacteriological characteristics of sachet water is safe for human consumption, the Nigeria based National Agency for Food and Drugs Administration Control (NAFDAC) in association with the World Health Organization (WHO), recommended that potable water for human consumption should not contain any microorganism that is known to be pathogenic and the coliform number per $100 \mathrm{ml}$ of water must be zero (WHO, 2006).

It is important to note that the findings of this study suggest that some of the brands of sachet water on sales in Owerri metropolis of Imo State, Southeastern Nigeria revealed the presence of pathogenic organisms in concentrations that make the products unfit for human consumption and do not conform to the international standards. For any water to conform with the international standard such water must be safe bacteriologically, biologically, chemically, and aesthetically. Therefore, some of the sachet water brands are not safe for drinking since pathogenic organisms were found to be present. In line with the assertions of Prasanna and Reddy (2009), we would also like to recommend the proper sanitary survey, design and implementation of water and or/ sanitation projects; regular disinfections, maintenances and supervisions of water sources, and regular bacteriological assessment of all water sources for drinking should be planned and conducted. There is therefore need for NAFDAC to intensify efforts in the routine monitoring of activities in the packaged drinking water industry. The safety of bottled and sachet drinking water should be ensured through comprehensive regulatory programs at both the federal and state levels. NAFDAC regulations for packaged waters should be protective of public health and there should be continuous adoption of packaged water quality standards. Testing of market samples will be a good way of detecting if the water is actually pure as claimed by these producing companies.

Assessment of sachet water quality at some important stages of production; pre-production, production and postproduction stages at the factories is therefore, suggested in order to ensure their quality and safety (Oladipo et al., 2009). Therefore, all water that fails NAFDAC and WHO regulations should be retreated before they are released to the public for human consumption. Also NAFDAC should intensify effort on batch number, production date and expiry date of all these sample vended in public (Oladipo et al., 2009). High premium should also be placed on ascertaining compliance with Good Manufacturing Practice (GMP) with emphasis on management of raw water source to the consumer product point as recommended by the International Bottled Water Association. Application of good manufacturing practices (GMP), strict process control and personal hygiene should be maintained at processing facilities.

Conclusively, most of the sachet water brands fell below WHO drinking water standards and are therefore of doubtful quality. Efforts need to be intensified in the monitoring of activities in this rapidly expanding industry with a view to raising standards (Oyedeji et al., 2010). The presence of pathogenic bacteria in this study may be as a result of improper handling, processing and purification procedures, unhygienic handling after production. Water with such bacteria are not safe for human consumption hence, the water source should be re-examined by the NAFDAC. To reduce contamination, further investigation on sachet water is recommended. Assessment of water quality at some important stages of production; preproduction, production and postproduction stages at the factories is therefore, suggested in order to ensure their quality and safety.

\section{REFERENCES}

Abayasekara, C. L., Herath, W. H. M. A. T., Adikaram, N. K. B., Chandrajith, R., Illapperuma, S. C., Sirisena, A.D. and Rajapura, S. G. (2007). 
Microbiological quality of bottled water in Sri Lanka: A preliminary Survey. Proceeding of the Peradeniya University Research Sessions, Sri Lanka, 12, 30.

Abed, K. F. and Alwakeel, S. S. (2007). Mineral and microbial contents of bottled and tap water in Riyadh, Saudi Arabia. Middle-East Journal of Scientific Researc2, 151-156.

Addo, K. K., Mensah, G. I., Bonsu, C. and Akyeh, M. L. (2009). Bacteriological Quality of Sachet Water Produced and Sold in Teshie-Nungua Suburbs of Accra, Ghana. African Journal of Food, Agriculture and Nutrition Development 9, 1-12.

Ajayi, A. A., Sridhar, M. K. C., Adekunle, L. V. and Oluwande, P. A. (2008). Quality of Packaged Waters Sold in Ibadan, Nigeria. African Journal of Biomedical Research 11(3), 251-258.

Anunobi, C. C., Onajole, A. T. and Ogunnowo, B. E. (2006). Assessment of the Quality of Packaged Water on Sale in Onitsha Metropolis. Nigerian Quarterly Journal of Hospital Medicine 16(2), 56-59.

Cheesbrough, M. (2006). District Laboratory Practice in Tropical Countries. Cambridge University Press. pp. 434.

Dada, A. C. (2009). Sachet Water Phenomenon in Nigeria: Assessment of the potential Health impacts. African Journal of Microbiology Research 3(1), 15-21.

Drinking Water Research Foundation (DWRF). 2004. Recent Developments in Bottled Water Quality and Safety Documentary Report. Alexandria, Virginia, U.S.A. pp. 1-9.

Egwari, L. O., Iwuanyanwu, S., Ojelabi, C. I., Uzochukwu, O. and Effiok, W. W. (2005). Bacteriology of Sachet Water Sold in Lagos, Nigeria. East African Medical Journal 82, 235-240.

Ehlers, M. M., Van Zyl, W. B., Pavlov, D. and Muller, E. (2004). Random survey of the microbial quality of bottled water in South Africa. Water SA. 30, 203-210.

Ekwunife, C. A., Okafor, S. O., Ukaga, C. N., Ozumba, N. A. and Eneanya, C. I. (2010). Parasites associated with sachet drinking water (Pure Water) in Awka, South-Eastern, Nigeria. Sierra Leone Journal of Biomedical Research 2(1), 23-27.

Jolt, J. G., Krieg, N. R., Sneath, P. H. A., Stanley, J. T. and Williams, S. T. (1994). Bergey's manual of systematic bacteriology, $9^{\text {th }}$ edn. Williams and Wilkins Co. Baltimore, Maryland. pp. 786.

Khaniki, G. R. J., Zarei, A., Kamkar, A., Fazlzadehdavil, M., Ghaderpoori, M. and Zareim, A. (2010). Bacteriological evaluation of bottled water from domestic brands in Tehran markets in Iran. World Applied Science Journal 8(3), 274-278.

Kokkinakis, E. N., Fragkiadakis, G. A. and Kokkinaki, A. N. (2008). Monitoring microbiological quality of bottled water as suggested by HACCP Methodology. Food Control 19, 57-961.

Kuitcha, D., Ndjama, J., Tita, A. M., Lienou, G., Kamgang, K., Beyala, V., Ateba, B. H. and Ekodeck, G. E. (2010). Bacterial contamination of water points of the upper Mfoundi watershed,
Yaounde, Cameroon. African Journal of Microbiology Research 4(7), 568-574.

Kwakye-Nuako, G., Borketey, P. B., Mensah-Attipee, I., Asmah, R. H. and Ayeh-Kumi, P. F. (2007). Sachet drinking water in Accra: The potential threats of transmission of enteric pathogenic Protozoan organisms. Ghana Medical Journal 41, 62-67.

Mpakam, H. G. (2009). Vulnérabilité à la pollution des ressources en eaux à Bafoussam et incidences socio-économiques et sanitaires: modalités d'assainissement. Th. Doct. PhD, Univ. Yaoundé I. pp. 267.

Okonko, I. O., Adejoye, O. D., Ogunnusi, T. A., Fajobi, E. A and Shittu, O. B. (2008). Microbiological and physicochemical analysis of different water samples used for domestic purposes in Abeokuta and Ojota, Lagos State, Nigeria. African Journal of Biotechnology 7(3), 617-621.

Oladipo, I. C., Onyenike, I. C. and Adebiyi, A. O. (2009). Microbiological analysis of some vended sachet water in Ogbomoso, Nigeria African Journal of Food Science 3(12), 406-412.

Onifade, A. K. and Ilori, R. M. (2008). Microbiological Analysis of Sachet Water Vended in Ondo State, Nigeria. Environmental Research Journal 2(3), 107110

Oyedeji, O., Olutiola, P. O. and Moninuola, M. A. (2010). Microbiological quality of packaged drinking water brands marketed in Ibadan metropolis and IleIfe city in South Western Nigeria. African Journal of Microbiology Research 4(1), 096-102.

Oyeleke, S. B. and Manga, S. B. (2008). Essentials of Laboratory Practicals in Microbiology. Tobest publisher, Minna, Nigeria. pp. 36-75.

Prasanna, R. B. and Reddy, M. S. (2009). Bacteriological examination of drinking water with reference to coliforms in Jeedimetla, Hyderabad, India. African Journal of Biotechnology 8(20), 5506-5507.

Taulo, S., Wetlesen, A., Abrahamsen, R., Mkakosya, R. and Kululanga, G. (2008). Microbiological quality of water, associated management practices and risks at source, transport and storage points in a rural community of Lungwena, Malawi. African Journal of Biotechnology 7(2), 131-137.

Wartburton, D., Harrison, B., Crawford, C., Foster, R., Fox, C., Gour, L. and Krol, P. (1998). A further review of the microbiological quality of bottled water sold in Canada, 1992-1997 survey results. International Journal of Food Microbiology 39, 221. 226.

World Health Organization (WHO) (2002). Heterotrophic Plate Count Measurement in Drinking Water Safety Management. WHO Public Health Expert Report, Geneva, Switzerland.

World Health Organization (WHO) (2006). Guidelines for drinking water quality, WHO, Geneva, $1^{\text {st }}$ addendum to $3^{\text {rd }}$ edn, Geneva. http://www.who.int/water sanitaion health/S 
Zamberlan, M. E., Rosangela, G. S., Guilhermetti, M., Filho, I. C., Eliana, H. E., Ueda-Nakamura, T. N., Nakamura, C. C. and Benedito, P. D. F. (2008). Comparison of the bacteriological quality of tap water and bottled mineral water. International Journal of Hygiene and Environmental Health 211, 504-509. 